\title{
Mobilisation of reserves during germination of Jatropha seeds ${ }^{1}$
}

\author{
Mobilização de reservas durante a germinação de sementes de Pinhão manso
}

\author{
Lineker de Sousa Lopes²*, Maria Izabel Gallão ${ }^{3}$ e Cândida Hermínia Campos de Magalhães Bertini ${ }^{4}$
}

\begin{abstract}
Phanerogam species reserve nutrients in their seeds in order to sustain propagation. Their chemical composition and the way the metabolites are used vary, according to genotype, the environment and the interaction between these factors. As the jatropha is considered a strategic oilseed crop in biofuel production, the aim of this work was to quantify the major reserve components (starch, protein, soluble sugar and lipid) of the jatropha seed and its disposition in the cells during different periods of germination, in order to understand the process of reserve mobilisation and to determine the potentially right time for the extraction of vegetable oil for that species. The seeds were soaked in water for $0 ; 12$; $24 ; 36 ; 42 ; 45$ and 48 hours, following a completely randomised design and evaluated for wet and dry biomass, chemical characteristics of the reserves and the disposition of the reserve compounds. Through research, it was observed that the levels of lipids increased up to $43 \%$ at the moment of protrusion. The carbohydrate levels, in both the endosperm and the embryo are minimal during protrusion and shortly after, indicating the maximum use of carbohydrates in the germination process. Greatest protein synthesis occurs with the greatest moisture gain, with a reduction in and agglomeration of protein bodies during embryo root growth after protrusion. Despite the presence of starch in the endosperm of jatropha curcas L., starch cannot be considered a source of sugars during the period of germination studied.
\end{abstract}

Key words: Jatropha curcas L.. Physiology. Oilseed crop.

\begin{abstract}
RESUMO - As espécies fanerógamas reservam nutrientes em suas sementes para sustentar sua propagação. A composição química e a forma de uso dos metabólitos são variáveis segundo o genótipo, o ambiente e interação desses fatores. O pinhão manso é considerado uma oleaginosa estratégica para produção de biocombustível, a partir disto, buscou-se quantificar os principais constituintes de reserva (amido, proteína, açúcar solúvel e lipídeo) da semente de pinhão manso e sua disposição nas células durante diferentes períodos germinativos, a fim de se conhecer o processo de mobilização de reservas e o momento potencialmente adequado à extração do óleo vegetal para a espécie. As sementes foram submetidas à embebição em água por $0 ; 12 ; 24 ; 36 ; 42 ; 45$ e 48 horas, segundo delineamento inteiramente casualizado e avaliadas quanto à biomassa úmida e seca, características químicas de reserva e disposição dos compostos de reserva. Com a pesquisa, observou-se que os teores de lipídeos se elevam em até $43 \%$ no momento da protrusão. Os teores de carboidratos, tanto no endosperma quanto no embrião, são mínimos durante a protrusão e logo após esta, indicando máximo uso de carboidratos nos processos da germinação. As maiores sínteses proteicas ocorrem nos instantes de maior ganho de umidade, ocorrendo também uma redução e aglomeração de corpos proteicos durante o período de crescimento radicular do embrião após a protrusão. Apesar da presença de amido no endosperma de Jatropha curcas L., não se pode considerar o amido uma fonte de açúcares durante o período germinativo estudado.
\end{abstract}

Palavras-chave: Jatropha curcas L.. Fisiologia. Oleaginosa.

\footnotetext{
*Autor para correspondência

${ }^{1}$ Recebido para publicação em 25/08/2011; aprovado em 19/11/2012

Pesquisa financiada pelo PET MEC/Sesu e CNPq

${ }^{2}$ Programa de Pós-Graduação em Agronomia/Fitotecnia, CCA/UFC, Caixa Postal: 6.035, Fortaleza-CE, Brasil, 60.356-000, linekerlk@gmail.com

${ }^{3}$ Departamento Biologia, CC/UFC, Fortaleza-CE, Brasil, edybel@ufc.br

${ }^{4}$ Departamento Fitotecnia, CCA/UFC, Fortaleza-CE, Brasil, bertini.candidabertini@gmail.com
} 


\section{INTRODUCTION}

Seeds have been studied as to the chemical composition of their reserves in order to determine their nutritional value and also because their reserve constituents are very useful in obtaining industrial products (ARRUDA et al., 2004).

Vegetable oils can become fuel for diesel engines, giving satisfactory calorific power, even though this may be less than with diesel made from petroleum. In Brazil, the main source of vegetable oil is soy, which accounts for over $70 \%$ of the biodiesel produced in the country (BRAZIL, 2009).

With the possibility of using jatropha oil for biodiesel production, there are prospects for growth for areas planted with this crop in the northeastern semiarid region. Arruda et al. (2004) report that the Jatropha is a plant with a low water requirement that tolerates well periods of drought, heat or cold, and that under extreme conditions of drought, the plant loses its leaves in order to conserve moisture in the tissue, which results in a break in growth; it therefore survives at the expense of the water and organic reserves stored in its stem. In Brazil under rainfed conditions, the plant grows in areas with rainfall ranging from 480 to 2,380 $\mathrm{mm}$ per year and average annual temperatures between 18 and $28.5^{\circ} \mathrm{C}$ (SARTUNINO et al., 2005).

The quality of the biodiesel produced depends on the composition of fatty acids. These differ in three characteristics: 1) size of the hydrocarbon chain, 2) the number of unsaturations, and 3) the presence of chemical groups. Biodiesel which has a predominance of combined monounsaturated fatty acids (oleic, ricinoleic) presents higher quality (COSTA et al., 2006).

According to Souza et al. (2009), jatropha seeds have about $40.33 \%$ lipids as well as $20.95 \%$ protein and $9.85 \%$ starch. From the start of germination to the growth of the seedlings, the reserve macromolecules are converted to soluble metabolites that can be mobilized and used to support growth and respiration, as well as other substances such as RNAm stored at the end of the maturation process (BEWLEY; BLACK 1994). During this period, the seedling should start photosynthetic activity before exhausting its reserves, so as to ensure successful colonization of the environment (EASTMOND; GRAHAM, 2001; GRAHAM, 2008).

The imbibition process of seeds was standardized by Bewley and Black (1994), following the triphasic model of a third-degree polynomial curve where $f(x)=a x^{3} \pm b x^{2} \pm$ $\mathrm{cx} \pm \mathrm{d}$, and $\mathrm{a}>0$. The first phase is characterized by rapid imbibition, which is due to the marked difference between the water potentials. The second phase is the moment of synthesis of the enzymes DNA and mRNA, which were depleted in phase one, and of drastic reductions in the hydration speed, its occurrence being dependent on the species studied. In the third phase, a resumption in growth of the embryo is seen, which is identified by protrusion of the main root.

Given the above, the objective was to quantify the major reserve components (starch, protein, soluble sugar and lipids) of the seed of the Jatropha, and their disposition in the cells during the different periods of germination, with a view to understanding the process of mobilization of reserves, and the most suitable time of the extraction of vegetable oil for this species.

\section{MATERIAL AND METHODS}

\section{Plant material and experimental setup}

The plant material used came from the Agricultural Research Corporation of Minas Gerais (Epamig), and grown in Minas Gerais for the 2006 harvest. The seed teguments were removed manually to facilitate imbibition and the observation of protrusion during germination.

The kernels (as seeds without teguments) were placed in germination boxes at an ambient temperature of about $25^{\circ} \mathrm{C}$, with a photoperiod of 12 hours of light, wrapped in pre-moistened germintest paper.

Samples of 20 kernels were taken at intervals of 12 hours from the start of imbibition until protrusion of the radicle. After protrusion, the criterion for removel of the samples was the size of the radicle. Seed samples taken at $42 ; 45$ and 48 hours after germinating presented radicles with a length of 3-5 $\mathrm{mm}, 5-7 \mathrm{~mm}$ and 7-11 mm respectively. The treatments were therefore days of germination $(\mathrm{T})$, where $\mathrm{T} 0$ represents the seed at the time of imbibition with distilled water, and T1, T2, T3, T4, T5 and T6 represent respectively those seeds with a period of imbibition of $12 ; 24 ; 36 ; 42 ; 45$ and 48 hours.

\section{Determination of moist and dry biomass}

Five kernels were randomly removed after each period of germination in accordance with the treatments. The kernels were weighed to obtain the amount of moist biomass, and then frozen to $-6{ }^{\circ} \mathrm{C}$ and then split into embryo and endosperm, and left to dry at $105^{\circ} \mathrm{C}$ for 24 hours to obtain the dry biomass.

\section{Cytochemical analysis}

The five seeds per replication, intended for cytochemical analysis were cut transversely, fixed in a solution of $4 \%$ paraformaldehyde and $1 \%$ glutaraldehyde 
in a buffer of sodium phosphate $0.02 \mathrm{M}, \mathrm{pH} 7.2$ for 24 hours at room-temperature. Once fixed, the material was dehydrated in an increasing array of ethanol and then soaked in historesin (Historesin Imbibition Kit-Jung).

Cuts of $5 \mu \mathrm{m}$ were made using a Leica RM 2065 automatic microtome. These were then subjected to the following cytochemical staining: a) Xylidine Ponceau (XP) $0.1 \% \mathrm{pH} 2.5$ to detect the total radical cation; b) PAS reaction (Periodic Acid-Schiff) of neutral polysaccharides.

\section{Chemical analysis}

For each of the germination periods defined by the treatments, fifteen kernels were randomly taken from the germination layer and frozen. Three replicates of $0.2 \mathrm{~g}$ of sample were used, obtained from the cuts made to separate the endosperm and the embryo, followed by maceration and drying.

The lipids were extracted chemically with cold hexane. The samples were exposed to hexane for $24 \mathrm{~h}$ after maceration, centrifuged, and the supernatants placed into test tubes of known weight. The samples were exposed to hexane for a further 20 minutes, centrifuged and the supernatants added to those from the first centrifugation. Determination was made by the difference in mass after the hexane had evaporated at room temperature.

The sugars were extracted using a sequence of reactions with $80 \%$ ethyl alcohol and quantified by readings from a spectrophotometer at a wavelength of 620 $\mathrm{nm}$ using the reagent anthrone and a reference curve from known concentrations of glucose for the quantification of soluble sugars, in accordance with Morris (1948).

Protein extraction was performed by reaction with $\mathrm{NaOH} 0.1 \mathrm{M}$, and quantified by the Bradford method (1976). In this method an albumin solution (BSA) is used as standard, and a spectrophotometer set up to measure the absorbance of light at a wavelength of $595 \mathrm{~nm}$ by a solution of $100 \mu \mathrm{L}$ of sample/mL of Bradford solution. Quantification of the existing proteins is made from the absorbance thus obtained and processed according to the regression equation of the standard solution of albumin (BSA), and the recorded absorbance.

The starch was quantified by the enzymatic method (AMARAL et al., 2007) using $\alpha$-amylase (120 $\mathrm{U} \mathrm{mL}^{-1}$ ) in a sodium phosphate buffer $(10 \mathrm{mM}, \mathrm{pH} 6.8)$ and amyloglucosidase $\left(30 \mathrm{U} \mathrm{mL}^{-1}\right)$ in a sodium acetate buffer (100 mM pH 4.5). The released glucose was quantified using the GOD-PAP enzyme kit (Bioclin) with readings from a spectrophotometer set to calculate the absorbance at a wavelength of $490 \mathrm{~nm}$.

\section{Statistical analysis}

Variance analysis was performed in accordance with ANOVA for a Completely Randomized Design (CRD), with seven treatments and three replications. A regression test for the variables was carried out with the $\mathrm{F}$ test significant to $5 \%$. Also a correlation test was performed using the Pearson coefficient, to verify the correlation between the variables analysed. The cytochemical analysis was merely descriptive.

The ASSISTAT and GENES statistical software were used (SILVA; AZEVEDO, 2002; CRUZ, 2006).

\section{RESULTS AND DISCUSSION}

The seeds accumulate their reserves in the endosperm, perisperm and embryo; more precisely in the cotyledons. In the case of the jatropha seed, nutritional reserves accumulate in the endosperm and very little in the embryo itself. During the germination process, mobilisation and morphological variation of nutrient molecules could be seen. The analysed seeds had kernels accounting for $63 \%$ of the seed mass.

Aftersoaking the jatrophaseeds inwatergermination starts, together with a set of processes associated with the early development of the embryo, which revert to the complexation chain of the reserve macromolecules such as lipids, which through the glyoxylate cycle sustain the increase in the respiration rate and growth of the embryo with ATP produced from the glucose formed in the cycle (EESTMOND, GRAHAM, 2001; GRAHAM, 2008).

In the variance analysis there are responses, significant to $1 \%$, for almost all the variables studied, except for the dry weight of the endosperm and the percentage of starch in the endosperm, which showed no significant differences (Tables 1 and 2).

Based on the moisture gain observed for each treatment (Table 1 and Figure 1) it can be seen that the process of germination of the Jatropha fits the triphasic model proposed by Bewley and Black (1994). Phase I of the model falls between T0 and T1 ( \pm 12 hours), a typical phase II falls between T1 and T2 ( \pm 12 hours) and phase III begins at T3. According to Marcos Filho (2005), the beginning of phases II and III does not involve the breaking off of previous phase(s) so that the seed can simultaneously display all three phases. This may explain the unexpected gain of moisture between T2 and T3, ie the moment after the beginning of phase II and prior to protrusion, which marks the beginning of phase III. The gain in moisture between T2 and T3 appears to be a manifestation of a latent phase I after the beginning of phase II. 
Table 1 - Summary of the variance analysis: seed moist weight (MWS); embryo dry weight (DWEM); endosperm dry weight (DWEN), embryo lipids (LEM), endosperm lipids (LEN) of the Jatropha, Fortaleza, Ceará, 2011

\begin{tabular}{|c|c|c|c|c|c|c|}
\hline \multirow{2}{*}{ Source of Variation (SV) } & \multirow{2}{*}{ GL } & \multicolumn{5}{|c|}{ - - } \\
\hline & & MWS & DWEM & DWEN & LEM & LEN \\
\hline Treat. (T) & 6 & $101034.71 * *$ & $74.79 * *$ & $1664.86^{\mathrm{ns}}$ & $56.48^{* * *}$ & $439.49 * *$ \\
\hline Residue (R) & 14 & 6914.28 & 6.03 & 826.00 & 5.72 & 26.21 \\
\hline CV (\%) & & 9.35 & 7.75 & 6.09 & 17.10 & 8.60 \\
\hline
\end{tabular}

* Value significant to $5 \%, * *$ value significant to $1 \%$ and ${ }^{\mathrm{ns}}$ valor non-significant to $5 \%$, by the $\mathrm{F}$ test

Table 2 - Summary of the variance analysis: embryo protein (PEM), endosperm protein (PEN), embryo sugar (SEM), endosperm sugar (SEN), endosperm starch (STEN) of the Jatropha, Fortaleza, Ceará, 2011

\begin{tabular}{|c|c|c|c|c|c|c|}
\hline \multirow{2}{*}{ Source of Variation (SV) } & \multirow{2}{*}{ GL } & \multicolumn{5}{|c|}{ } \\
\hline & & PEM & PEN & SEM & SEN & STEN \\
\hline Treat. (T) & 6 & $7.10 * *$ & $151.97 * *$ & $0.12 * *$ & $7193657.42 * *$ & $0.04^{\mathrm{ns}}$ \\
\hline Residue (R) & 14 & 0.01 & 0.55 & 0.01 & 9999.99 & 0.02 \\
\hline CV (\%) & & 3.28 & 2.78 & 31.31 & 4.74 & 12.68 \\
\hline
\end{tabular}

$*$ Value significant to $5 \%$, ** value significant to $1 \%$ and ${ }^{\text {ns }}$ valor non-significant to $5 \%$, by the $\mathrm{F}$ test

During germination the dry weight of the embryo increased by $62.4 \%$, from $23.25 \mathrm{mg}$ to $37.25 \mathrm{mg}$, the gain in dry weight being more significant in phase I and at the end of phase II, quite near the start of phase III, coinciding with the times when greater amounts of

Figure 1 - Seed moist weight during germination of the Jatropha (Jatropha curcas L.) as a function of germination time, Fortaleza, 2011

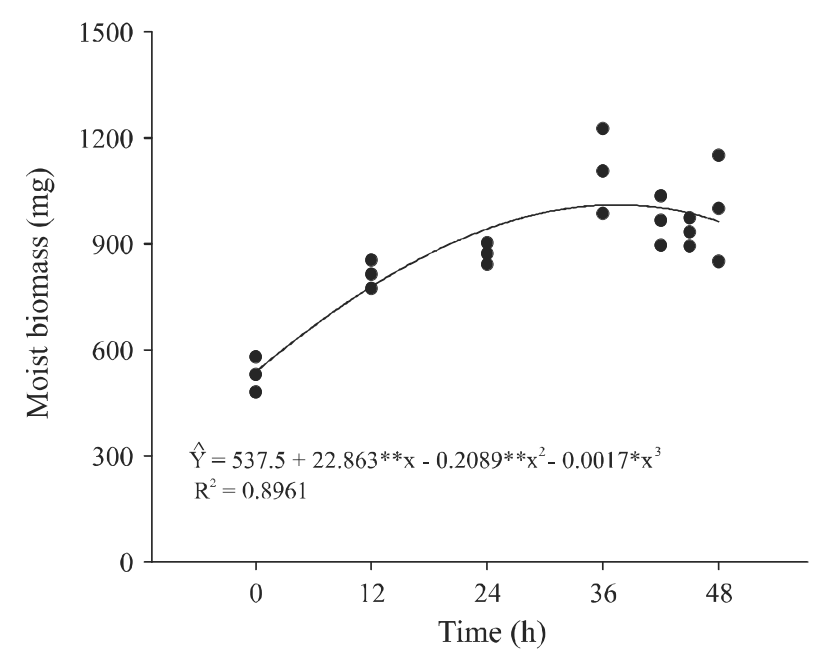

$*$ Value significant to $5 \%$,** value significant to $1 \%$ and ${ }^{\mathrm{Ns}}$ valor non-significant to $5 \%$, by the $\mathrm{F}$ test water entered the seed (Figure 2). There was a positive correlation of 0.93 , significant to $5 \%$, between the wet and dry weight of the embryo indicating that the gains in dry weight of the embryo accompany the gains in moisture from imbibation of the seeds.

Figure 2 - Embryo dry weight during seed germination of the Jatropha (Jatropha curcas L.) as a function of germination time, Fortaleza, 2011

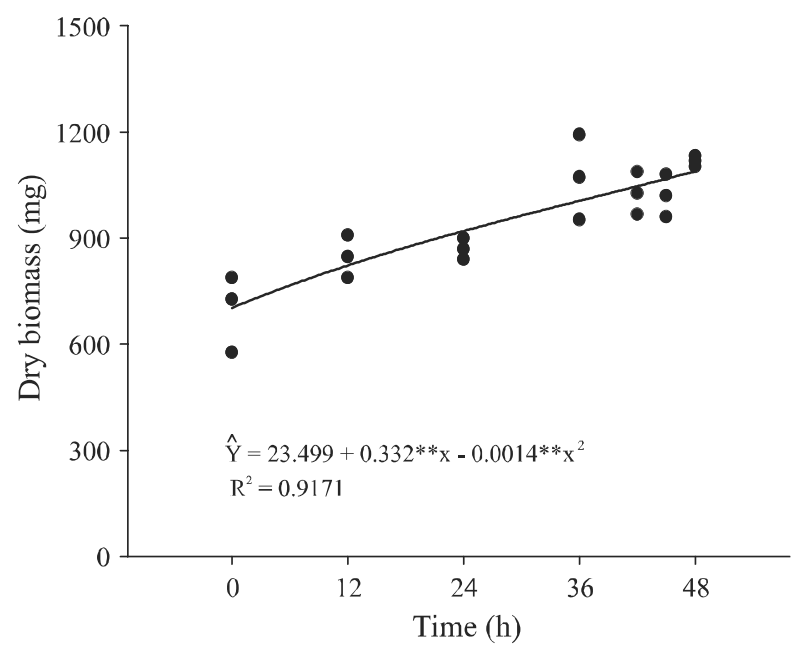

$*$ Value significant to $5 \%, * *$ value significant to $1 \%$ and ${ }^{\mathrm{Ns}}$ valor non-significant to $5 \%$, by the $\mathrm{F}$ test 
The endosperm presents an average dry weight of $471.39 \mathrm{mg}$. During the 48 hours of the germination process studied, there was no significant difference in endosperm dry weight using the F test (Table 1). This occurs possibly due to the high ratio of endosperm to embryo dry weight (21:1 ratio), which turns the losses in endosperm dry weight hardly significant in sustaining the gains in embryo dry weight.

Based on the embryonic growth seen in Figure 2, the statistical analysis of the values which result from the chemical analysis of the embryo could not be made based on content as in the case of the endosperm, since the embryonic growth would mask the changes in metabolites due to the dilutive effect. The statistical analyses therefore were based on the absolute value of the metabolites found in the embryonic tissues.

The trend lines based on the regression analysis carried out for lipids, protein and soluble sugars, enable the behavior of these reserve compounds in the endosperm and embryo tissue during germination to be seen (Figure 3).

The main metabolic substances of economic interest in the seeds of the Jatropha are the lipids, not for any nutritional value but because it is a raw material for the bio-fuel industry (ARRUDA et al., 2004). In both the endosperm and the embryo a synthesis of lipids occurs during the 12 hours preceding protrusion, thus increasing the oil content of the seed by $19.52 \%$ from $56.42 \%$ to $75.52 \%$ of the kernel dry weight, this being a significant increase and one that can be exploited to maximize the extraction of oil from jatropha seeds (Figure 3A and 3B). However it is unclear how this synthesis alters the composition of fatty acids in the oil, which can affect the quality of any biodiesel produced (COSTA et al., 2006).

Between T0 and $\mathrm{T} 1$ and between $\mathrm{T} 2$ and $\mathrm{T} 3$ there was an increase in protein in both the endosperm and embryo (Figure 3C and 3D). The increased protein content in the endosperm, in the moments prior to protrusion, is another characteristic of phases I and II of the triphasic model. In the first phase, one of the signs of reactivation of the metabolism is the synthesis of proteins from the RNAm which is stored at the end of the maturation process, a break in imbibition then occurs which is characteristic of the second phase, being explained as a "pause" for the replacement of enzymes and RNA depleted in phase I of the same model (BEWLEY; BLACK, 1994). After protrusion, there was also protein synthesis in the embryo for a further nine hours, possibly sustained by amino acids moved from the endosperm to the embryo. Lima et al. (2008) observed an oscillation of the protein content during germination of Aniba rosaeodora seeds, similar to that of the Jatropha.
A correlation of 0.84 was also seen between the protein content of the endosperm and of the humid biomass, significant to $1 \%$. This indicates that protein synthesis is linked to moisture gain. Thus the increase in embryo dry weight in phases I and II, which is associated with the gain in moisture, can be explained by the synthesis of protein (Figure 3D) and other structural compounds, sustained by moving sugar from the endosperm to the embryo ( Figure 3E).

From the results of the cytochemical analysis, it was seen that the Xylidine ponceau (XP) stained the cytoplasmic content, indicating the presence of cationic compounds such as proteins. The cytoplasmic region was heavily stained, indicating protein bodies dispersed throughout the cytoplasm, these show as globular corpuscles of small dimensions. The presence of many globular corpuscles, heavily stained with XP, was also observed in the cytoplasm of cotyledon cells of Cesalpinia peltophoroides (CORTE et al., 2006) and of Prosopis juliflora (GALLÃO et al., 2007). Starting after protrusion, a reduction and clustering of protein bodies was seen; this reduction can also be seen from the protein content of the endospermic cells (Figure 3C, $4 \mathrm{~A}, 4 \mathrm{~B}$ and $4 \mathrm{C})$.

The sugar reserves are consumed continuously for the production of ATP in the embryo, the consumer center, as that is where there is an accelerated formation of new cells. A reduction of soluble sugars is clearly observed between $\mathrm{T} 0$ and $\mathrm{T} 3$, the period that precedes protrusion in all kernels (Figure 3E and 3F). The movement of sugar to the embryo can be observed by the negative correlation of -0.92 between the sugar content in the endosperm and in the embryo dry biomass, significant to 5\%. Despite the continuous high demand for energy in the embryo, an accumulation of sugars from T3 is seen (Figure 3E and 3F). This may be the result of a greater supply of sugar, resulting from the conversion of endosperm lipids, and also to a small reduction in the energy requirement, since a negative correlation between sugar and protein can be seen in both the embryo (-0.88) and the endosperm (-0.86), significant to $5 \%$.

Unlike other species, such as Caesalpinia echinata and Caesalpinia ferrea, which also show accumulated starch in the reserve tissues, the Jatropha does not use starch as its main reserve material (TEIXEIRA; MACHADO, 2008). The starch cannot be considered a source of sugars during the germination period under study since this concentration remained stable according to the F test, around $53.35 \mathrm{mg} / \mathrm{L}$ of glucose being released by enzymatic reactions, corresponding to $10.67 \mathrm{mg} / \mathrm{g}$ DM of the Jatropha kernel (Table 2). The observed starch content was 9.2 times lower than that of $9.85 \%$ obtained by Souza et al. (2009). 
Figure 3 - Trend line of the endosperm lipid content (A), embryo lipid content (B), ebdosperm protein content (C), embryo protein content (D), endosperm sugar content (E) and embryo sugar content(F) of jatropha seeds in germination

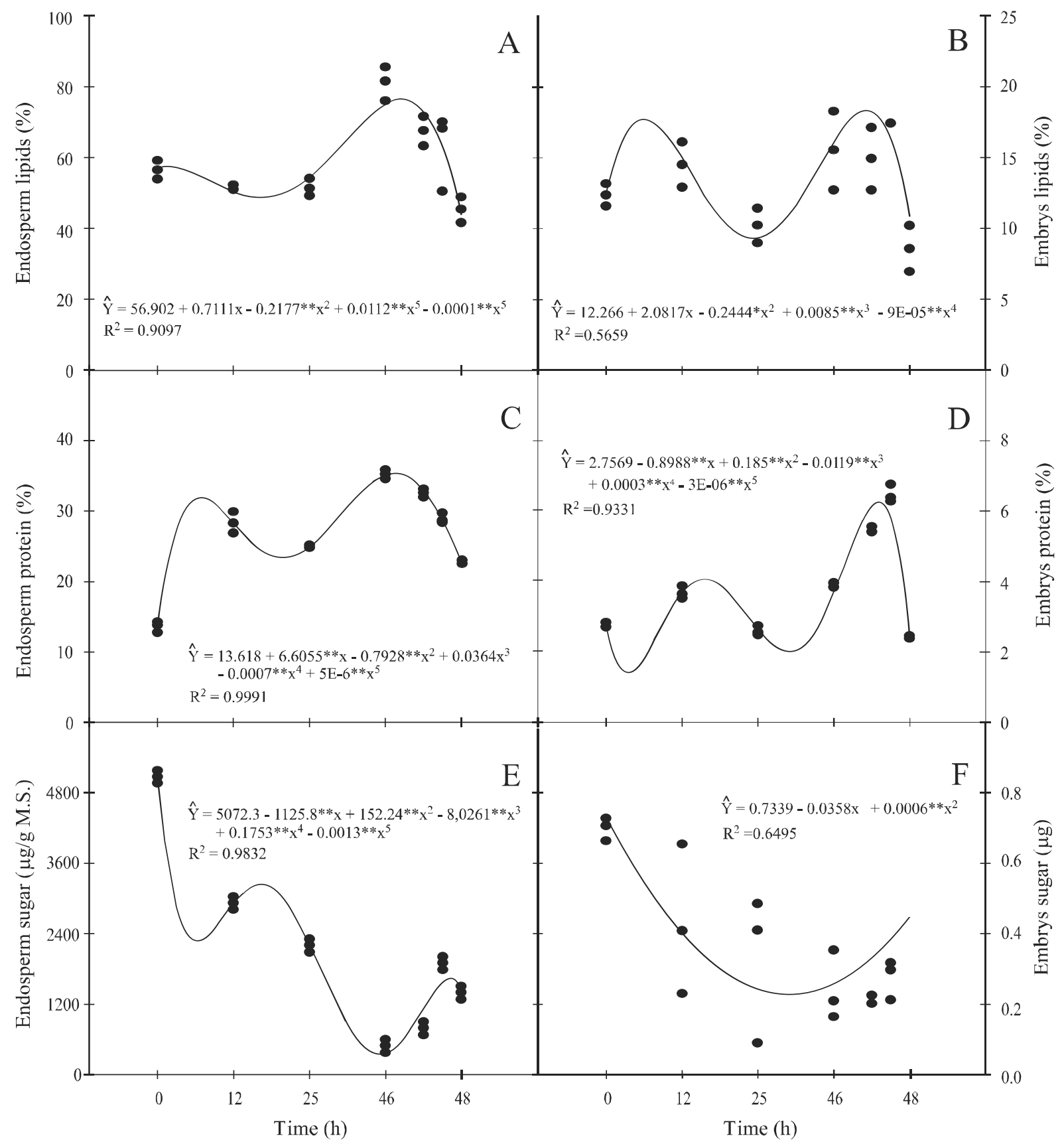

$*$ Value significant to $5 \%, * *$ value significant to $1 \%$ and ${ }^{\mathrm{NS}}$ valor non-significant to $5 \%$, by the $\mathrm{F}$ test

Viewing the starch by PAS in the endosperm tissue, only becomes evident from T2 onwards, this is possibly due to the large amount of protein that prevents the starch from being seen (Figure 4A, 4D and $4 \mathrm{E}$ ). The same problem of masking of the starch by proteins was reported by Gallão et al. (2006) in seeds of Moringa oleifera.
According to Suda and Giorgini (2000) the accumulation of soluble sugars in the embryo of Euphorbia heterophylla occurs throughout germination. In the Jatropha, accumulation only begins at 9 hours after protrusion, because until T5 the energy demand exceeded the extra supply of sugar derived from the endosperm (Figure 3E and 3F). 
Figure 4 - Cross section of endosperm of the Jatropha (Jatropha curcas L.) stained with XP at T0 (A), T3 (B), T6 (C) Cross Section and endosperm of the Jatropha submitted to the PAS reaction T0 (D), T2 (E), T5 (F)
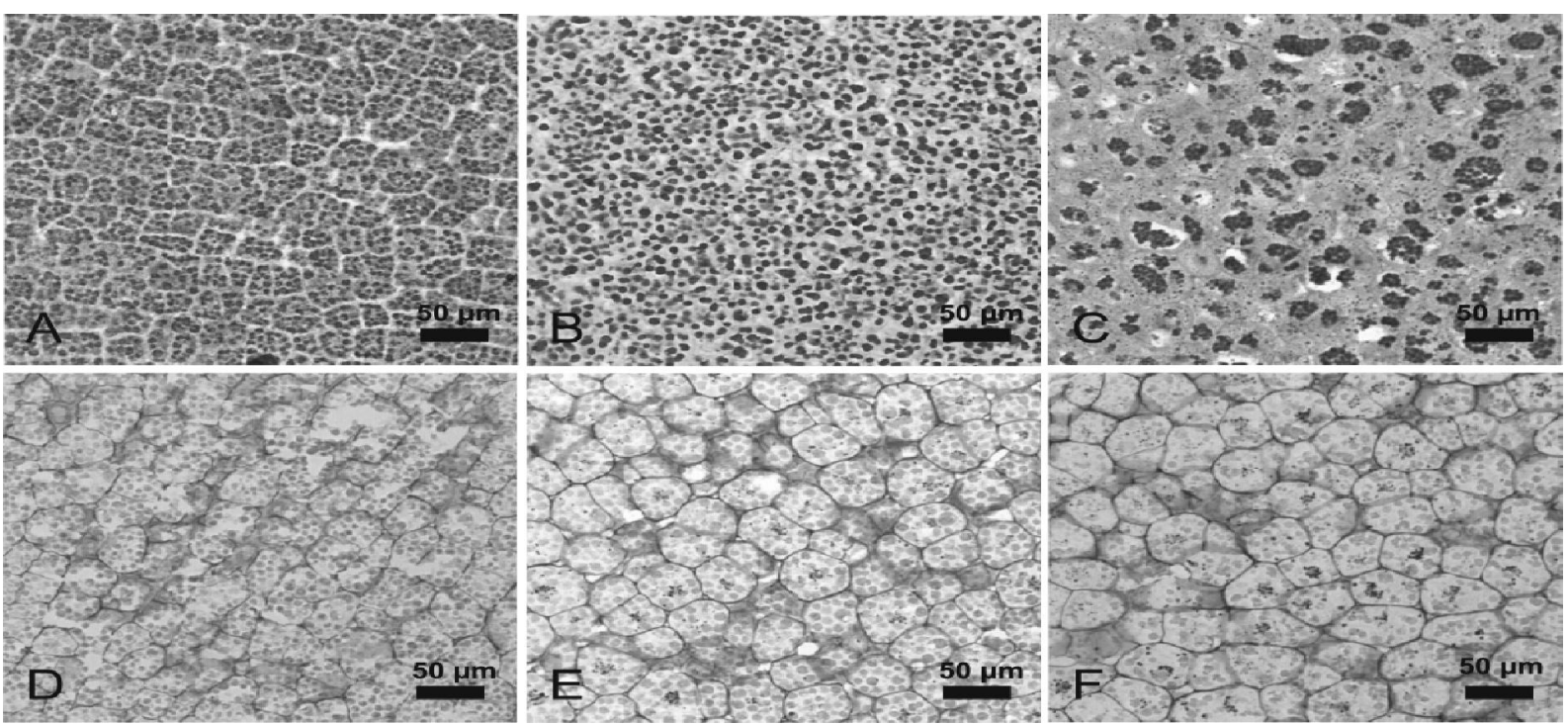

In Arabidopsis thaliana (L.) Heynh. The mobilization of lipid reserves is inhibited in the presence of soluble sugars such as glucose and sucrose, which generally stem from the metabolism of starch (TO et al. 2002). The same seems to happen in the Jatropha because the greatest decrease in lipids in the endosperm coincides with the reserves of sugar being at a minimum in the endosperm (Figure 3A and 3E).

Suda and Giorgini (2000) found a reduction in lipid content between 72 and 96 hours of imbibition in the embryo of Euphorbia heterophylla. In the Jatropha, there was a fluctuation in the amount of lipids in the embryo during germination, minimum values being observed at 24 and 48 hours of imbibition. Synthesis of lipids in the endosperm can be seen to accompany protein synthesis in the endosperm at a correlation of 0.91 , significant to $5 \%$.

\section{CONCLUSIONS}

1. The imbibition curve for jatropha seeds fits the Bewley and Black model (1994);

2. The levels of lipids rise by up to $19.52 \%$ at the moment of protrusion, this being therefore potentially the most suitable time to extract the maximum oil possible;

3. The carbohydrate content in both the endosperm and the embryo is less both during and shortly after protrusion, indicating the maximum use of carbohydrates by the processes of germination;
4. There is greater protein synthesis at moments of greater moisture gain, and a reduction and clustering of protein bodies during the period of embryo root-growth after protrusion;

5. Despite the presence of starch in the endosperm of the Jatropha, this cannot be considered as a source of sugars during the studied germination period because the concentration of starch remained stable according to the $\mathrm{F}$ test.

\section{ACKNOWLEDGEMENTS}

To SESu, especially the Tutorial Education Program (PET), and to CNPq, for their financial support.

\section{REFERENCES}

AMARAL, L. I. V. et al. Novo método enzimático rápido e sensível de extração e dosagem de amido em materiais vegetais. Hoehnea, v. 34, n. 4, p. 425-431, 2007.

ARRUDA, F. P. et al. Cultivo de pinhão manso (Jatropha curcas L.) como alternativa para o semiárido nordestino. Revista brasileira de oleaginosas e fibrosas, v. 8 , n. 1, p. 789-799, 2004.

BEWLEY, J. D.; BLACK, M. Seeds: Physiology of development and germination. New York: Plenum Press, 1994. 445 p.

BRADFORD, M. M. A rapid and sensitive method for the quantifications of microgram quantities of protein utilizing the 
principle of protein-dye binding. Analitycal Biochemistry, v. 72, p. 248-254, 1976.

BRASIL. Ministério de Minas e Energia. Boletim mensal dos combustíveis renováveis, n. 20, 2009. Disponível em: <http:// www.mme.gov.br>. Acesso em: 2 maio 2010.

CORTE, V. B. et al. Mobilização de reservas durante a germinação das sementes e crescimento das plântulas de Caesalpinia peltophoroides Benth. (Leguminosae Caesalpinoideae). Revista Árvore, v. 30, n. 6, p. 941-949, 2006.

COSTA, B. J.; OLIVEIRA, S. M. M. Produção de biodiesel. Instituto de tecnologia do Paraná, 2006. Dossiê técnico. Disponível em: <http://sbrt.ibict.br/acessoDT/304> Acesso em: 17 jan. 2011.

CRUZ, C. D. Programa Genes: biometria. Viçosa, MG: UFV, 2006. $382 \mathrm{p}$.

EASTMOND, P. J.; GRAHAM, I. A. Re-examining the role of the glyoxylate cycle in oilseeds. Plant Science, v. 6, n. 2, p. 72-77, 2001.

GALLÃO, M. I. et al. Reserve mobilisation in mesquite (Prosopis juliflora) seed (Leguminosae). Journal of the Science of Food and Agriculture, v. 87, n. 11, p. 2012-2018, 2007.

GALLÃO, M. I.; DAMASCENO, L. F.; BRITO, E. S. Avaliação química e estrutural da semente de moringa. Revista Ciência Agronômica, v. 37, n. 1, p. 106-109, 2006.

GRAHAM, I. A. Seed storage oil mobilization. Annual Review of Plant Biology, v. 59, n. 1, p. 115-142, 2008.
LIMA, R. B. S. et al. Primary metabolite mobilization during germination in rosewood (Aniba roseodora Ducke) seeds. Revista Árvore, v. 32, n. 1, p. 19-25, 2008.

MARCOS FILHO, J. Fisiologia de sementes de plantas cultivadas. 12. ed. Piracicaba: Fealq, 2005. 495 p.

MORRIS, D. L. Quantitative determination of carbohydrates with Drywood's anthrone reagent. Science, v. 107, n. 3, p. 254-255, 1948.

SARTUNINO, M. H. et al. Produção de oleaginosas para biodiesel. Informe Agropecuário, v. 26, n. 229, p. 44-78, 2005.

SILVA, F. A. S.; AZEVEDO, C. A. V. de. Versão do programa computacional Assistat para o sistema operacional Windows. Revista Brasileira de Produtos Agroindustriais, v. 4, n. 1, p. 71-78, 2002.

SOUZA, A. D. V. et al. Caracterização química de sementes e tortas de Pinhão manso, Nabo-forrageiro e Crambe. Pesquisa Agropecuária Brasileira, v. 44, n. 10, p. 1328-1335, 2009.

SUDA, N. K. C.; GIORGINI, J. F. Seed reserve composition and mobilization during germination and initial seedling development of Euphorbia heterophylla. Revista Brasileira de Fisiologia Vegetal, v. 12, n. 3, p. 226-245, 2000.

TEIXEIRA, S. P.; MACHADO, S. R. Storage sites in seeds of Caesalpinia echinata and C. ferrea (leguminosae) with considerations on nutrients flow. Brazilian Archives of Biology and Technology, v. 51, n. 1, p. 127-136, 2008.

TO, J. P. C.; REITER, W.; GIBSON, S. I. Mobilization of seed storage lipid by Arabidopsis seedlings is retarded in the presence of exogenous sugars. BMC Plant Biology, v. 2, p. 4-15, 2002. 